Importance of sensory evaluation in assessment of egg quality

Važnost senzorne evaluacije u procjeni kvalitete jaja

Margeta, P., Kralik, G., Grčević, M., Hanžek, D., Kralik, Z.

Poljoprivreda/Agriculture

ISSN: 1848-8080 (Online)

ISSN: 1330-7142 (Print)

http://dx.doi.org/10.18047/poljo.25.1.8

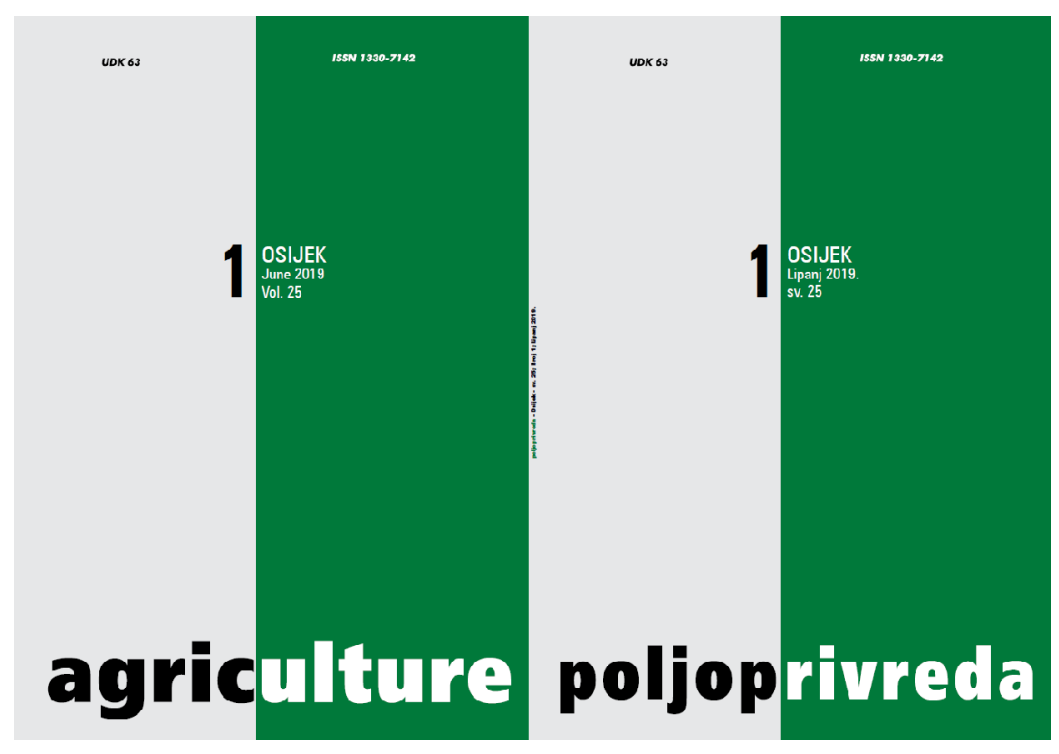

Fakultet agrobiotehničkih znanosti Osijek, Poljoprivredni institut Osijek

Faculty of Agrobiotechnical Sciences Osijek, Agricultural Institute Osijek 
ISSN $1330-7142$

$U D K=637.4: 338.518$

DOI: $10.18047 /$ poljo.25.1.8

\title{
IMPORTANCE OF SENSORY EVALUATION IN ASSESSMENT OF EGG OUALITY
}

Margeta, $P^{(1,2)}$, Kralik, G. ${ }^{(2)}$, Grčević, M. ${ }^{(1,2)}$, Hanžek, D. ${ }^{(1,2)}$, Kralik, Z..$^{(1,2)}$

\author{
Scientific review \\ Pregledni znanstveni članak
}

\section{SUMMARY}

The sensory evaluation is a scientific discipline used to evoke, measure, analyze and interpret reactions to stimuli perceived through senses of sight, smell, touch, taste, and hearing. Sensory evaluation applies principles of experimental design and statistical analysis to the use of human senses aiming to isolate the sensory properties of foods themselves and provide important and useful information to product developers, food scientists, and managers about the sensory characteristics of food products. To achieve the scientific control of the sensory evaluation test, good laboratory practice should be applied. It includes defining the test objective and test type, selection of right assessors, ensuring right test area, handling and preparing the sample in appropriate way, paying attention to test set-up and storing the test data safe in logical order.

Regarding eggs, sensory characteristics are usually evaluated on eggs enriched with bioactive compounds. Sensory studies are often conducted either with trained (in accordance with international reference standards) or untrained panelists. Sensory evaluation of eggs after addition of different compounds is of great importance because sensory attributes such as aroma, flavor, aftertaste and overall acceptability of enriched eggs are very important to consumers.

Key words: eggs, sensory evaluation, food-enrichment

\section{INTRODUCTION TO SENSORY EVALUATION}

The sensory evaluation is a scientific discipline used to evoke, measure, analyze and interpret reactions to stimuli perceived through senses of sight, smell, touch, taste, and hearing (Stone and Sidel, 2004). The field of sensory evaluation grew rapidly in the second half of the twentieth century, along with the expansion of the processed food and consumer products industries. Sensory evaluation applies principles of experimental design and statistical analysis to the use of human senses with the attempt to describe the sensory properties of foods and provides important and useful information to product developers, food scientists, and managers about the sensory characteristics of food products (Lawless and Heymann, 2010).

Sensory evaluation gives guidelines for the preparation and serving of samples under controlled conditions so that factors with potential influence to the results are minimized. Numerical data are collected to establish appropriate relationships between product characteristics and human perception (Watts et al., 1989).

Data generated from human observers are often highly variable, so proper statistical analysis and interpretation of the data is a critical part of sensory testing. Conclusions should involve consideration of the method, the limitations of the experiment, the background and contextual framework of the study. They also should include reasoned judgments based upon data, analyses,

(1) Polonca Margeta, Ph.D. (pmargeta@fazos.hr), Manuela Grčević, Ph.D., Danica Hanžek, M. Eng. Agr., Assoc. Prof. Zlata Kralik, Ph.D. Josip Juraj Strossmayer University of Osijek, Faculty of Agrobiotechnical Sciences Osijek, Vladimira Preloga 1, 3100 Osijek, Croatia; (2) Prof. Emer. Dr. h. c. Gordana Kralik, Ph.D. - Josip Juraj Strossmayer University of Osijek, Scientific Center of Excellence for Personalized Health Care, Trg Sv. Trojstva 3, 31000 Osijek, Croatia 
and results. In sensory test procedures, it is desirable to minimize error variance as much as possible to obtain results that are low in error associated with repeated measurements which can be partially achieved by training of panel participants. Next concern is the accuracy (validity) of a test because the test results should reflect the perceptions and opinions of consumers that might buy the product. In considering validity, the end use of the information provided by a test should be taken into account. Another error that may occur are false positive results and the effects of random chance deviations must be considered in deciding if a test results reflect a real difference or whether results are likely to be due to chance variation (Mason and Nottingham, 2008; Lawless and Heymann, 2010).

\section{SENSORY EVALUATION IN ACADEMIC RESEARCHES}

Academic research on foods and materials and their properties and processing often require sensory tests to evaluate the human perception of changes in the products (Lawless and Klein, 1989). An important function of sensory scientists is to provide consulting and resources to insure that quality tests are conducted by other researchers and students who seek to understand the sensory impact of the variables they are studying.

To achieve the scientific control of the sensory evaluation test, good laboratory practice should be applied. It includes defining the test objective and test type, selection of right assessors, ensuring right test area (light and air quality, noise, space), handling and preparing the sample in appropriate way, paying attention to test set-up as well as storing the test data safe in logical order (Kuti, 2015).

Most frequently used sensory test procedures could be divided on analytical tests and affective (hedonic) tests (Mason and Nottingham, 2008).

\section{Analytical tests}

Analytical panels are used as measuring instruments and they should to be able to measure appropriate parameters and to be reproducible as well. Analytical sensory tests include difference tests which may be further sub-divided into simple difference tests, having no direction or characteristic associated with the difference between products and directional difference tests dealing with characteristic associated with the difference between the products. Applications of difference tests are as follows:

- to determine the effect of changes in raw material, process and packaging on finished product,

- to investigate the presence of off-flavors and taints,

- verifying changes to formulation during product development.
Statistical analysis of difference testing data depends on whether the data are graded. Then t-test or analysis of variance are applied or the data are categorized as right or wrong answers and the binominal distribution is used (Mason and Nottingham, 2008).

Among analytical tests, descriptive sensory analyses are the most sophisticated techniques allowing the sensory scientist to obtain complete sensory descriptions of the products, identify underlying ingredient and process variables and to determine which sensory attributes are important to be accepted. With sensory profiling more than two samples can be simultaneously assessed. To conduct a generic descriptive analysis, 8 to 12 panelists, trained in accordance with international reference standards (ISO standards) are employed. They usually use a quantitative scale for intensity which allows the data to be statistically analyzed.

Applications of descriptive testing are:

- tracking sensory characteristics changes over time (shelf-life evaluation),

- defining sensory properties for new product development,

- examining sensory characteristics of different varieties of a product,

- sensory diagnostics of ingredient, process or packaging changes,

- describing product attributes prior to consumer testing,

- defining the characteristics (specification) of a control or standard.

This type of a test has the advantage of not only being able to discriminate the difference between samples but also determine the nature and magnitude of these differences (Mason and Nottingham, 2008; Lawless and Heymann, 2010). Statistics methods used for descriptive testing rating or preference type data are paired t-test and analysis of variance, as well as some advanced methods for separating data into logical groups using Principal Component Analysis (Castada et al., 2019).

\section{Affective (hedonic) tests}

Consumers' sensory impressions of food are the major determinant of the consumer's subsequent purchasing behavior. Information on consumer likes and dislikes, preferences, and requirements for acceptability can be obtained using consumer-oriented testing methods and untrained sensory panels. Affective tests involve consumer preference or acceptance and are usually performed toward the end of the product development. However, at this time the alternative product prototypes have usually been narrowed down to a manageable subset through the use of analytical sensory tests. In affective testing large random sample of people, representative of the target population of potential users is selected to obtain information on consumers' attitudes or preferences. In foods and consumer products, there 
are two main approaches to consumer sensory testing, the measurement of preference and the measurement of acceptance (Jellinek, 1964). Preference can be either overall or in relation to a particular parameter. It describes a preference for one product over another. Acceptance infers actual utilization or the product purchase. In the measurement of acceptance or liking, the consumers rate their liking for the product on a scale. Acceptance measurements can be done on single products and do not require a comparison to another product.

Hedonic tests have no need for training of panelists, nevertheless, they should be instructed regarding method, questionnaire, length of trial and number of samples. However, discussing the actual food to be tested should be avoided. Twenty to 100 panelists are applied in these tests. In consumer sensory analysis researchers are interested in whether the consumers like the product, prefer it over another product, or find the product acceptable based on its sensory characteristics (Lim, 2011).

Preference testing is referred to consumer tests in which the consumer is given the choice and asked to indicate their most liked product. Several types of preference tests exist:

- paired preference test: panelists have to decide, which of two samples they prefer,

- replicated preference test: replication as consequence that many people change their minds from trial to trial,

- ranking: consumers are asked to rank products in either descending or ascending order of preference of liking.

- rating for preference: assessors are asked to evaluate one or more samples and indicate the degree of liking.

Acceptability tests provide some information on whether the product is liked or disliked in some absolute sense. Liking is measured with response scales (Methven et al., 2016). The response scale is usually divided into an arbitrary number of categories - usually between 7 and 13. The most common hedonic scale is the 9-point hedonic scale, also known as a degree of liking scale. Another popular scale that combines intensity and hedonic judgments is the just-about-right (JAR) scale (Li et al., 2014). The end anchors are "Too little" and "Too much" and the center point is labelled "just about right". The just-about-right scales are popular for the direct information that they give on specific attributes to be optimized. There is variety of other useful methods available to assess acceptability of products and the relative preferences among a set of choices. In spite of the obvious importance of product acceptability, this group of sensory methodologies is prone to misuse and misinterpretation, and the aim of the sensory research is to present only enough information so that the product is evaluated within the correct reference frames. For example, participants in a sensory acceptance test are given a product with a random three-digit code. They only know that it is a test of scrambled eggs, and they are unaware that the eggs are frozen, reconstituted, microwaved, cholesterol reduced, or any number of other factors that might eventually have impact on the product concept. What matters only is their acceptability to consumers on the basis of their sensory attributes (taste, texture, appearance, etc.) (Rothman and Parker, 2009).

\section{New approaches - transfer of sensory methods to the consumer}

A transfer of sensory methods to the consumer includes description of product characteristics from the consumer perspective (penalty analysis, napping - rapid method, temporal methods) and measuring of the product shelf-life with consumers (survival analysis).

Penalty analysis has been used by practitioners in the industry to identify decreases in acceptability associated with sensory attributes not at optimal levels in a product. It is a way to analyze the JAR data in order to quantify and hierarchize the impact of the overall liking of the product. In addition, liking data needs to be collected, for which the 9-point hedonic scale is frequently used. Penalty analysis provides a prioritized list of critical product characteristics that are most-penalizing product performance (Kuti, 2015).

Napping is a rapid sensory profiling technique which uses a sheet of paper or table top to represent the sensory space of a product set; products are placed on the sheet according to their sensory differences/similarities to produce a sensory map (Lé et al., 2015). Samples that are placed close together are more similar and those that are placed further apart are more different. It is used for quick identification and characterization of overall differences and similarities among a set of larger number of product samples (more then 10).

Temporal dominance of sensations (TDS) is a rapid descriptive method that offers a different magnitude of information to traditional descriptive analysis methodologies. This methodology considers the dynamic nature of eating, assessing sensory perception of foods as they change throughout the eating event. It is a multidimensionality approach, assessing the changes in the dominant sensory attributes over time, without being limited to singular attributes (Pineau et al., 2009). This technique assesses changes in the sensory profile over time, and has been proven useful when the product of interest has a persisting aftertaste (Labbe et al., 2009).

A survival analysis can be applied in sensory analyses to determine the shelf-life of foods. It gives answer to the question how much the product can change before consumers reject it. The survival function was defined as the probability of consumers accepting a product beyond a certain storage time. In food shelflife studies, samples with different storage times are presented to consumers. The survival analysis in food shelf-life studies measures the storage time the consumer rejects the sample at (Hough et al., 2003). Kralik et al. (2017) informed about the storage time effect on table eggs quality. 


\section{IMPORTANCE OF SENSORY EVALUATION IN ASSESMENT OF EGG QUALITY}

Sensory analyses on eggs are conducted mostly for two reasons:

1. in terms of determining overall egg quality and characteristics after enrichment with different bioactive components.

2. assessing impact of different housing or production systems, mostly conventional and organic, on egg sensory properties.

The production of healthier eggs by increasing the amount of the long-chain unsaturated fatty acids (FA) such as $\alpha$-linoleic, eicosapentaenoic and docosapentaenoic is a modern way to improve the nutritional value of eggs. Typical oils added to the hen's diet are fish, flax, canola, soybean, hampseed and algae oils (Van Elswyk, 1997; Elkin et al., 2015; Ehr et al., 2017, Konca et al., 2019). In studies with tailored combinations of dietary fats, more specific eggs with modified fatty acid compositions have been developed (Yalçin and Ünal, 2010). A problem in using of marine/fish meals and oils in layer diet is fishy taste, fishy odour and fishy off-flavor, which are considered to be the major undesirable side-effects when including high $\omega-3$ FA levels in the diets fed to hens (Parpinello et al., 2006; Toyes-Vargas et al., 2018). Sensory changes are less noticeable, but still present, after addition of a-linoleic acid-rich ingredients such as flaxseed and hempseed oil (Goldberg et al., 2012).

An increase in the content of PUFAs in dietary products causes additional lipid oxidation and can induce negative effect on sensory characteristics. To maintain egg quality and sensory attributes, the fatty acid stability should be increased. It is achieved through addition of both synthetic and natural antioxidants, for example thymus meal (Tserveni-Gousi, 2001).

Other possible reasons that may cause unwanted sensory changes are the strain and age of the hens as well as the storage of eggs.

When the effects of housing systems are compared (organic or free-range vs. conventional in cages), majority of researches deal with differences in chemical composition and nutrient content of eggs (Karsten et al., 2010; Rakonjac et al., 2014), the impact of housing systems on the hygienic quality and safety of eggs (Hidalgo et al., 2008). Nevertheless, some rare studies include also comparison of sensory attributes of eggs produced in different housing systems (Rossi, 2007; Terčič, 2012). Mizumoto et al. (2008) found no significant sensorial differences between hard-boiled eggs from cage, semiorganic and organic systems. Similar Rossi (2007) found no difference among overall taste acceptability of hard-boiled eggs from cage, litter and organic systems.

\section{SENSORY EVALUATION METHODS IN ASSESMENT OF EGG SENSORY ATTRIBUTES}

Any enrichment of eggs with bioactive compounds having favorable impact on consumers health can increase consumer acceptance of egg products, but only if eggs maintain their compositional stability and are sensorial acceptable. For that reason, sensory or organoleptic attributes are usually evaluated in studies performed on eggs enriched with bioactive components (Hayat et al., 2010). Conventional sensory analyses are conducted either with trained or untrained panelists to score eggs regarding their sensory characteristics and sensory attributes such as aroma, flavor, after-taste and overall acceptability.

In order to perform sensory analysis on eggs, the recruitment and sensory evaluation protocols usually first become an ethical approval from relevant institutions. The criteria for participation include open availability, an interest in the panel, and no aversion or allergies to eggs. A written consent from panelists is obtained (Hayat et al., 2010; Goldberg et al., 2012).

In sensory evaluation panels with trained panelists, the number of panelists ranges from 8 to 10 . Before actual sensory analysis panelists have to attend few (mostly 6) training sessions where they review testing procedure, egg evaluation techniques and evaluate the aroma and flavor of experimental coded samples. During training sessions, panelists develop and agree vocabulary of attributes (Goldberg et al., 2012). In some studies, panelists were selected and trained according to international standards (Petrović et al., 2016).

Sensory tests started with sample preparation. Eggs were mostly boiled for different time, in general for 10 to 15 minutes. Sometimes, homogenized egg samples were fried or prepared in microwave oven (Petrović et al., 2016). In majority studies, samples were cooled to room temperature, only in Goldberg et al. (2012), egg samples were kept in glass jars during sensory analysis at a constant temperature of $55^{\circ} \mathrm{C}$. The samples were, then, coded with a randomly selected 3-digit numbers.

The sensory methods used for determination of egg sensory attributes depended largely on whether trained or untrained panelists were included. The final purpose of the sensory test was very important in choosing the right method. Depending on the method, different statistical approaches were implemented for data analysis.

Goldberg et al. (2012; 2016) employed 8 trained panelists for descriptive sensory analysis, where the aroma and flavor attributes of different egg samples were scored on unstructured $15 \mathrm{~cm}$ line scales from 0 (low) to 15 (high). The panelists were provided with filtered, room temperature water and unsalted cracker to cleanse their palate between tasting. Eggs from different dietary treatments were replicated 3 times on 3 separated days within a week. Sensory data were analyzed with 3-way analysis of variance (ANOVA) and with PASW and IBM SPSS Statistics. Tukey's test was used to determine mean treatment differences when significant $(P<0.05)$. A bi-plot was generated for all sensory attributes to provide a visual perspective of the correlation between the samples and sensory attribute intensities.

Trained panelists evaluated test samples with respect to how different they were from the control in the sensory 
evaluation test performed by Hayat et al. (2010). Tested sensory attributes included aroma (odor of the whole egg), flavor (distinctive aroma and taste of the yolk), off-flavors (unusual smell or taste of the yolk) and overall difference. They rated differences between each sample and the control using a 9-point intensity scale where 0 was for no difference and 9 extremely different. The panelists were also allowed to write comments on what they thought about the major differences. Beside trained panelists, the samples were evaluated also by untrained panelists and consumers, based on triangular test. Each was given 3 samples, 2 of which were similar (from the same egg) and the third was different. Participants were asked to recognize the different egg sample based on aroma and flavor. For statistical analysis, an individual ANOVA was conducted for each attribute using SAS.

The triangle difference test was employed also by Williams and Damron (1999). Sensory sessions consisted of comparing the control to the two test samples with the highest addition of tested substance in the feed. The untrained panelists were asked to identify the "odd" sample, record whether it differed in flavor or texture, and comment on any other differences that were noticed. Data collected by the Triangle difference test were complied and computed to determine statistical significance based on the number of correct responses.

Sensory analyses of eggs by Petrović et al. (2016) were conducted by two sensory tests. The sensory test using response scale where the obtained numerical values indicated the quality of studied sensory properties (in compliance with international standard ISO 4121:2003) evaluated characteristics of hardboiled eggs, including one control and four experimental samples. Each panelist was asked to evaluate appearance, color, taste, flavor, off-flavor, texture and overall acceptability using a numeric unipolar discrete response scale (1-very bad, 10-excellent). In addition, ranking was carried out to evaluate hedonic preference of the control and experimental groups of egg samples. Panelists evaluated the samples and placed them in the preference rank order, according to the international standard ISO 8587:2006. Analysis of variances for sensory evaluations was performed by using Statistica software. Means were compared using Tukey's test for multiple comparisons. A probability level of $P<0.05$ was considered statistically significant.

An unstructured numerical scale (from 1 to 7 ) was applied by Terčič et al. (2012), where 1 point meant that the trait was not expressed or that it was unacceptable, while 7 points meant that the trait was strongly or excellently expressed. For descriptive analysis panelists participated in 6 training sessions where they evaluated the aroma and flavor of coded samples, developed and agreed vocabulary of attributes consisted of 7 aroma and 6 flavor attributes. Other products (dairy products, chicken broth, kelp tablets, saline solution) were also evaluated and used as reference points for each attribute.

\section{CONCLUSION}

The field of sensory evaluation grew rapidly in the second half of the twentieth century along with the expansion of the processed food and consumer products industries. Sensory evaluation applies principles of experimental design and statistical analysis to the use of human senses aiming to isolate the sensory properties of foods themselves and provides important and useful information to product developers, food scientists, and managers about the sensory characteristics of food products.

Academic research on foods and materials, their properties and processing often require sensory tests to evaluate the human perception of changes in the products. To achieve the scientific control of the sensory evaluation tests, good laboratory practice should be applied. It includes defining the test objective and test type, selection of right assessors, ensuring right test area (light and air quality, noise, space), handling and preparing the sample in appropriate way, paying attention to test set-up and storing the test data safe in logical order.

Sensory test procedures could be divided on analytical tests and affective (hedonic) tests.

Analytical panels are used as measuring instruments and they need to be valid (able to measure appropriate parameters) and reproducible. Applications of analytical tests are in determining the effect of changes in the procedure on finished product to investigate the presence of off-flavors, taints and verify changes to formulation during product development. Descriptive sensory analyses are the most sophisticated techniques among analytical tests. They allow the sensory scientist to obtain complete sensory descriptions of the products, identify underlying ingredient and process variables, as well as to determine which sensory attributes are important to acceptance.

Affective tests involve consumer preference or acceptance and are usually performed toward the end of the product development, with the aim to collect information on consumer likes and dislikes, preferences, and requirements for acceptability and are performed by untrained sensory panels.

A transfer of sensory methods to the consumer is a new approach, which includes description of product characteristics from the consumer perspective and measuring of the product shelf-life with consumers.

Sensory analyses on eggs are conducted mostly in terms of determining overall egg quality and characteristics after enrichment with different bioactive components and for assessing impact of different housing or production systems, mostly conventional and organic on egg sensory properties.

Anny enrichment of eggs with bioactive compounds with favorable impact on health of consumers can increase consumer acceptance of egg products, but only if eggs maintain their compositional stability and are sensorial 
acceptance. Conventional sensory analyses are conducted either with trained or untrained panelists to score eggs regarding their sensory characteristics and attributes such as aroma, flavor, after-taste and overall acceptability.

In order to perform sensory analysis on eggs, the recruitment and sensory evaluation protocols usually first become an ethical approval from relevant institutions. The criteria for participation include open availability, an interest in the panel and no aversion or allergies to eggs.

The sensory methods used for determination of egg sensory attributes depended largely on whether trained or untrained panelists were included. The final purpose of the sensory test was very important in choosing the right method. Depending on method, different statistical approaches were implemented for data analysis.

Sensory tests provide useful information about the human perception of product changes due to ingredients,

processing, packaging, or shelf life. Sensory information reduces risk in decisions about product development and strategies for meeting consumer needs which insures a greater chance of marketplace success. The utility of the information provided is directly related to the quality of the sensory measurement.

The use of novel feed ingredients in laying hen diet must be weighed against any potential changes of the sensory attributes of the resultant eggs. Sensory analyses should, therefore, become an indispensable part of researches regarding eggs, enriched in different bioactive compounds.

\section{ACKNOWLEDGEMENT}

This study is supported by the European Structural and Investment Funds grant for the Croatian National Scientific Center of Excellence for Personalized Health Care (grant \#KK.01.1.1.01.0010) and by Ministry of Science and Education of the Republic of Croatia.

\section{REFERENCES}

1. Castada, H. Z., Hanas, K. \& Barringer, S.A. (2019). Swiss Cheese Flavor Variability Based on Correlations of Volatile Flavor Compounds, Descriptive Sensory Attributes, and Consumer Preference. Foods, 8(78). https://doi.org/10.3390/foods8020078

2. Ehr, I. J., Persia, M. E., \& Bobeck, E. A. (2017). Comparative omega-3 fatty acid enrichment of egg yolks from first-cycle laying hens fed flaxseed oil or ground flaxseed. Poultry Science, 96(6), 1791-1799. https://doi.org/10.3382/ps/pew462

3. Elkin, R. G., Ying, Y., \& Harvatine, K. J. (2015). Feeding laying hens stearidonic acid-enriched soybean oil, as compared to flaxseed oil, more efficiently enriches eggs with very long-chain n-3 polyunsaturated fatty acids. Journal of Agricultural and Food Chemistry, 63(10), 2789-2797. https://doi.org/10.1021/jf505185u

4. Goldberg, E. M., Gakhar, N., Ryland, D., Aliani, M., Gibson, R. A., \& House, J. D. (2012). Fatty acid profile and sensory characteristics of table eggs from laying hens fed hempseed and hempseed oil. Journal of Food Science 77(4), 53-60.

https://doi.org/10.1111/j.1750-3841.2012.02626.x

5. Goldberg, E. M., Ryland, D., Aliani, M., \& House, J. D. (2016). Interactions between canola meal and flaxseed oil in the diets of White Lohmann hens on fatty acid profile and sensory characteristics of table eggs. Poultry Science, 95(8), 1805-1812. https://doi.org/10.3382/ps/pew025

6. Hayat, Z., Cherian, G., Pasha, T. N., Khattak, F. M., \& Jabbar, M. A. (2010) Sensory evaluation and consumer acceptance of eggs from hens fed flax seed and 2 different antioxidants. Poultry Science, 89(10), 2293-2298. https://doi.org/10.3382/ps.2009-00575

7. Hidalgo, A., Rossi, M., Clerici, F., \& Ratti, S. (2008). A market study on the quality characteristics of eggs from different housing systems. Food Chemistry, 106(3), 1031 1038. https://doi.org/10.1016/j.foodchem.2007.07.019

8. Hough, G., Langohr, K., Gómez, G., \& Curia, A. (2003). Survival Analysis Applied to Sensory Shelf Life of Foods. Journal of Food Science, 68(1), 359-362. https://doi.org/10.1111/j.1365-2621.2003.tb14165.x

9. Jellinek, G. (1964). Introduction to and critical review of modern methods of sensory analysis (odour, taste and flavour evaluation) with emphasis on descriptive sensory analysis (flavour profile method). Journal of Nutrition Dietetics, 1, 219-260.

10. Karsten, H. D., Patterson, P. H., Stout, R., \& Crews, G. (2010). Vitamins A, E and fatty acid composition of the eggs of caged hens and pastured hens. Renewable Agriculture and Food Systems, 25(1), 45-54. https://doi.org/10.1017/S1742170509990214

11. Konca, Y., Yuksel, T., Yalcin, H., Beyzi, S.B., \& Kaliber, M. (2019). Effects of heat-treated hempseed supplementation on performance, egg quality, sensory evaluation and antioxidant activity of laying hens. British Poultry Science, 60(1), 39-46. https://doi.org/10.1080/00071668.2018.1547360

12. Kralik, Z., Grčević, M., Kralik, G., Hanžek, D., \& Zelić, A. (2017). Quality of table eggs on the Croatian market. Poljoprivreda, 17(1): 63-68.

http//doi.org/10.18047/poljo.23.1.10

13. Kutti, T. (2015). Importance of the sensory and consumer methods for food businesses. Retrieved from: www. gzs.si/Portals/Panoga-Kmetijska-Zivilska/9_Tunde\%20 Kuti.pdf

14. Labbe, D., Schlich, P., Pineau, N., Gilbert, F., \& Martin, N. (2009). Temporal Dominance of Sensations and Sensory Profiling: A Comparative Study. Food Quality and Preference, 20(3), 216-221.

https://doi.org/10.1016/j.foodqual.2008.10.001

15. Lawless, H., \& Heymann, H. (2010). Sensory Evaluation of Food, Science Principles and Practices. Springer, $2^{\text {nd }}$ Edition, Ithaca, New York.

16. Lawless, H. T., \& Klein, B. P. (1989). Academic vs. industrial perspectives on sensory evaluation. Journal of Sensory Studies, 3(3), 205-216. https://doi.org/10.1111/j.1745-459X.1989.tb00445.x 
17. Lê, S., Le, T., \& Cadoret, M. (2015). Napping and sorted Napping as a sensory profiling technique. Rapid Sensory Profiling Techniques and Related Methods: Applications in New Product Development and Consumer Research. https://doi.org/10.1533/9781782422587.2.197

18. Li, B., Hayes, J. E., \& Ziegler, G. R. (2014). Just-AboutRight and ideal scaling provide similar insights into the influence of sensory attributes on liking. Food quality and preference, 37, 71-78. https://doi.org/10.1016/j.foodqual.2014.04.019

19. Lim, J. (2011). Hedonic scaling: A review of methods and theory. Food Quality and Preference, 22, 733-747. https://doi.org/10.1016/j.foodqual.2011.05.008

20. Mason, R. L., \& Nottingham, S.M. (2008). Food 3007 and Food 7012, Sensory Evaluation Manual. The University of Queensland.

21. Methven, L., Jiménez-Pranteda, M.L. \& Lawlor, J.B. (2016). Sensory and consumer science methods used with older adults: A review of current methods and recommendations for the future. Food Quality and Preference, 48, Part B, 333-344. https://doi.org/10.1016/j.foodqual.2015.07.001

22. Mizumoto, E. M., Canniatti-Brazaca, S. G., \& Machado, F. M. V. F. (2008). Chemical and sensorial evaluation of eggs obtained by different production systems. Food Science and Technology, 28(1), 60-65. https://doi.org/10.1590/S0101-20612008000100010

23. Parpinello, G. P., Meluzzi, A., Sirri, F., Tallarico, N., \& Versari, A. (2006). Sensory evaluation of egg products and eggs laid from hens fed diets with different fatty acid composition and supplemented with antioxidants. Food Research International, 39(1), 47-52. https://doi.org/10.1016/j.foodres.2005.05.010

24. Petrović, M., Karačić, V., Mazija, H., Vahčić, N., \& Medić, H. (2016). Stability and sensory evaluation of eggs produced by addition of different amount of linseed oil into feed. Croatian Journal of Food Technology, Biotechnology and Nutrition, 11(1-2), 41-48. Retrieved from: https://hrcak.srce.hr/166829

25. Pineau, N., Schlich, P., Cordelle, S., Mathonnière, C., Issanchou, S., Imbert, A., ...\& Köster, E. (2009). Temporal Dominance of Sensations: Construction of the TDS curves and comparison with time-intensity. Food Quality and Preference, 20(6), 450-455. https://doi.org/10.1016/j.foodqual.2009.04.005

26. Rakonjac, S., Bogosavljević-Bošković, S., Pavlovski, Z., Škrbić, Z., Dosković, V., Petrović, M., \& Petričević, V. (2014). Laying hen rearing systems: A review of major production results and egg quality traits. World's Poultry Science Journal, 70(1), 93-104.

https://doi.org/10.1017/S0043933914000087

27. Rossi, M. (2007). Influence of the laying hen housing systems on table egg characteristics. In European Symposium on the Quality of Eggs and Egg Products (pp. 49-51). WPSA Czech Branch.

28. Rothman, L., Parker, M. J. (2009). Just-About-Right (JAR) Scales: Design, Usage, Benefits, and Risks. American Society for Testing \& Materials.

29. Stone, H., \& Sidel, J. L. (2004). Sensory Evaluation Practices. Academic Press Inc., Tragon Corporation, Redwood City.

30. Terčič, D., Zlender, B., \& Holcman, A. (2012). External, Internal and Sensory Qualities of Table Eggs as Influenced by Two Different Production Systems. Agroznanje, 13(4), 555-562. https://doi.org/10.7251/AGREN1204555T

31. Toyes-Vargas, E., Ortega-Pérez, R., EspinozaVillavicencio, J. L., Arellano-Pérez, M., Civera, R., \& Palacios, E. (2018). Effect of marine by-product meals on hen egg production parameters, yolk lipid composition and sensory quality. Journal of Animal Physiology and Animal Nutrition, 102(2), 462-473. https://doi.org/10.1111/jpn.12769

32. Tserveni-Gousi, A. S. (2001). Sensory evaluation of eggs produced by laying hens fed diet containing flaxseed and thymus meal. Archiv für Geflugelkunde, 65(5), 214-218. Retrieved from: https://www.european-poultry-science. com/artikel.dll/2001-65-214-218_NDk2MDI4MO.PDF

33. Van Elswyk, M. (1997). Comparison of $n-3$ fatty acid sources in laying hen rations for improvement of whole egg nutritional quality: A review. British Journal of Nutrition, 78(1), 61-69. https://doi.org/10.1079/BJN19970135

34. Yalçin, H., \& Ünal, M. K. (2010). The enrichment of hen eggs with omega-3 fatty acids. Journal of Medicine Food, 13(3), 610-614. https://doi.org/10.1089/jmf.2008.0024

35. Watts, B. M., Ylimaki, G. L., Jeffery, L.E. \& Elias, L. G. (1989). Basic sensory methods for food evaluation. International Development Research Centre, Ottawa, Ontario, Canada.

36. Williams, S. K., \& Damron B. L. (1999). Sensory and fatty acid profile of eggs from commercial hens fed rendered spent hen meal. Poultry Science, 78(4), 614-617. https://doi.org/10.1093/ps/78.4.614 


\section{VAŽNOST SENZORNE \\ EVALUACIJE U PROCJENI KVALITETE JAJA}

\section{SAŽETAK}

Senzorna procjena je znanstvena disciplina koja se koristi za evociranje, mjerenje, analizu i tumačenje reakcija na podražaje koji se percipiraju kroz osjetila vida, mirisa, dodira, okusa i sluha. Senzorna procjena primjenjuje načela eksperimentalnoga oblikovanja i statističke analize za korištenje ljudskih osjetila u pokušaju izoliranja osjetilnih svojstava hrane i daje važne i korisne informacije proizvođačima, znanstvenicima koji se bave hranom te menadžerima o osjetilnim karakteristikama prehrambenih proizvoda. Da bi se postigla znanstvena kontrola senzornoga testa procjene, potrebno je primijeniti dobru laboratorijsku praksu, koja uključuje definiranje cilja i tipa ispitivanja, odabir pravih procjenitelja, osiguravanje odgovarajućega područja ispitivanja, rukovanje $i$ pripremanje uzorka na odgovarajući način, vodeći računa o tome da je postavljanje ispitivanja i pohranjivanje podataka ispitivanja sigurno i u logičkom redoslijedu.

Kada se radi o jajima, osjetilna svojstva obično se procjenjuju na jajima obogaćenim bioaktivnim spojevima. Senzorne studije često se (u skladu s međunarodnim referentnim standardima) provode $s$ obučenim ili neobučenim panelistima. Senzorna procjena jaja nakon dodavanja različitih spojeva od izuzetne je važnosti, jer su senzorna obilježja, kao što su aroma, okus, naknadni okus i sveukupna prihvatljivost obogaćenih jaja, vrlo važna potrošačima.

Ključne riječi: jaja, senzorna procjena, obogaćivanje hrane

(Received on February 1, 2019; accepted on March 22, 2019 - Primljeno 1. veljače 2019.; prihvaćeno 22. ožujka 2019.) 